\title{
Insulin resistance, hypertension and microalbuminuria in patients with Type 2 (non-insulin-dependent) diabetes mellitus
}

\author{
L. Groop, A. Ekstrand, C. Forsblom, E. Widén, P.-H. Groop, A.-M. Teppo, J. Eriksson \\ Fourth Department of Medicine, Helsinki University Hospital, Helsinki, Finland
}

Summary. We examined the impact of hypertension and microalbuminuria on insulin sensitivity in patients with Type 2 (non-insulin-dependent) diabetes mellitus using the euglycaemic insulin clamp technique in 52 Type 2 diabetic patients and in 19 healthy control subjects. Twenty-five diabetic patients had hypertension and 19 had microalbuminuria. Hypertension per se was associated with a $27 \%$ reduction in the rate of total glucose metabolism and a $40 \%$ reduction in the rate of non-oxidative glucose metabolism compared with normotensive Type 2 diabetic patients (both $p<0.001$ ). Glucose metabolism was also impaired in normotensive microalbuminuric patients compared with normotensive normoalbuminuric patients $(29.4 \pm 2.2$ vs $40.5 \pm 2.8 \mu \mathrm{mol} \cdot \mathrm{kg}$ lean body mass $^{-1} \cdot \mathrm{min}^{-1} ; p=0.012$ ), primarily due to a reduction in non-oxidative glucose metabolism $\left(12.7 \pm 2.9\right.$ vs $21.1 \pm 2.6 \mu \mathrm{mol} \cdot \mathrm{kg}$ lean body mass ${ }^{-1}$. $\left.\min ^{-1} ; p=0.06\right)$. In a factorial ANOVA design, however, only hypertension $(p=0.008)$ and the combination of hypertension and microalbuminuria $(p=0.030)$ were significantly associated with the rate of glucose metabolism. The highest triglyceride and lowest HDL cholesterol concentrations were observed in Type 2 diabetic patients with both hypertension and microalbuminuria. Of note, glucose metabolism was indistinguishable from that in control subjects in Type 2 diabetic patients without hypertension and microalbuminuria $(40.5 \pm 2.8$ vs $44.4 \pm 2.8 \mu \mathrm{mol} \cdot \mathrm{kg}$ lean body mass $^{-1} \cdot \min ^{-1}$ ). We conclude that insulin resistance in Type 2 diabetes is predominantly associated with either hypertension or microalbuminuria or with both.

Key words: Type 2 (non-insulin-dependent) diabetes mellitus, insulin resistance, hypertension, lipids, microalbuminuria.
Insulin resistance has been considered a constant feature of both Type 2 (non-insulin-dependent) diabetes mellitus [13] and hypertension [4] and non-obese hypertensive Type 2 diabetic patients have been considered more insulin resistant than normotensive diabetic patients [5]. Microalbuminuria, i.e. overnight urinary albumin excretion rate (AER) above $20 \mu \mathrm{g} / \mathrm{min}$ predicts overt diabetic nephropathy in both patients with Type 1 (insulin-dependent) [6, 7] and Type 2 diabetes [8]. In addition, microalbuminuria is associated with increased cardiovascular mortality in patients with Type 2 diabetes $[9,10]$. Only a small proportion of this excess cardiovascular mortality in Type 2 diabetes can be explained by end-stage renal failure. The causal relationship between microalbuminuria and cardiovascular disease is, however, unknown. Microalbuminuria is associated with hypertension and dyslipidaemia $[11,12]$,i.e.high VLDL triglycerides and low HDL cholesterol in Type 2 diabetic patients. The combination of Type 2 diabetes with obesity, hypertension and the above-mentioned dyslipidaemia has been called an insulin resistance syndrome since insulin resistance has been considered the common denominator of these abnormalities [2]. There is, however, no information available on whether microalbuminuria is associated with insulin resistance, nor are there any quantitative data on the impact of hypertension, microalbuminuria, or both, on insulin sensitivity in patients with Type 2 diabetes. Given these potential connections between insulin resistance, hypertension and microalbuminuria, the present study was designed to examine the impact of hypertension and microalbuminuria on insulin sensitivity in patients with Type 2 diabetes.

\section{Subjects and methods}

\section{Subjects}

Three groups of subjects were studied: a) 19 Type 2 diabetic patients with microalbuminuria (MA+), albumin excretion rate (AER $>20 \mu \mathrm{g} / \mathrm{min}$ in at least two of three overnight urine specimens) and b) 33 Type 2 diabetic patients with normoalbuminuria (MA -) 
Table 1. Clinical and metabolic characteristics of Type 2 diabetic patients and healthy control subjects

\begin{tabular}{|c|c|c|}
\hline & $\begin{array}{l}\text { Control } \\
\text { subjects }\end{array}$ & $\begin{array}{l}\text { Type } 2 \text { diabetic } \\
\text { patients }\end{array}$ \\
\hline$n$ & 19 & 52 \\
\hline Age (years) & $54.6 \pm 2.5$ & $59.0 \pm 0.9$ \\
\hline $\mathrm{BMI}\left(\mathrm{kg} / \mathrm{m}^{2}\right)$ & $26.7 \pm 0.5$ & $27.1 \pm 0.5$ \\
\hline $\mathrm{FPG}(\mathrm{mmol} / \mathrm{l})$ & $5.1 \pm 0.1$ & $11.4 \pm 0.4^{\mathrm{a}}$ \\
\hline $\mathrm{HbA}_{1 \mathrm{c}}(\%)$ & $5.2 \pm 0.1$ & $8.0 \pm 0.2^{\mathrm{a}}$ \\
\hline Fasting insulin (pmol/l) & $43 \pm 5$ & $80 \pm 7^{a}$ \\
\hline Fasting NEFA $(\mu \mathrm{mol} / \mathrm{l})$ & $628 \pm 41$ & $721 \pm 29$ \\
\hline Total cholesterol (mmol/l) & $6.20 \pm 0.23$ & $6.53 \pm 0.21$ \\
\hline HDL cholesterol (mmol/l) & $1.24 \pm 0.07$ & $1.22 \pm 0.05$ \\
\hline Triglycerides (mmol/l) & $1.67 \pm 0.20$ & $2.29 \pm 0.21^{c}$ \\
\hline $\begin{array}{l}\text { Total glucose metabolism } \\
\left(\mu \mathrm{mol} \cdot \mathrm{kg} \mathrm{LBM}^{-1} \cdot \mathrm{min}^{-1}\right)\end{array}$ & $44.4 \pm 2.8$ & $31.9 \pm 1.9^{\mathrm{a}}$ \\
\hline 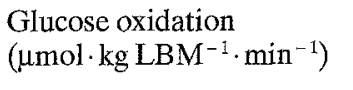 & $21.9 \pm 1.2$ & $17.9 \pm 0.6^{b}$ \\
\hline 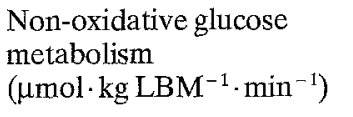 & $27.1 \pm 2.0$ & $13.9 \pm 1.4^{\mathrm{a}}$ \\
\hline $\begin{array}{l}\text { Basal hepatic glucose } \\
\text { production }(\mu \mathrm{mol} / \mathrm{min})\end{array}$ & $153 \pm 9$ & $209 \pm 7^{\mathrm{a}}$ \\
\hline $\begin{array}{l}\text { Clamp hepatic glucose } \\
\text { production }(\mu \mathrm{mol} / \mathrm{min})\end{array}$ & $4 \pm 3$ & $37 \pm 4^{\mathrm{a}}$ \\
\hline 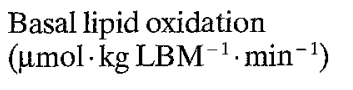 & $4.13 \pm 0.29$ & $5.27 \pm 0.18^{\mathrm{b}}$ \\
\hline $\begin{array}{l}\text { Clamp lipid oxidation } \\
\left(\mu \mathrm{mol} \cdot \mathrm{kg} \mathrm{LBM}{ }^{-1} \cdot \mathrm{min}^{-1}\right)\end{array}$ & $2.02 \pm 0.35$ & $3.24 \pm 0.16^{b}$ \\
\hline
\end{tabular}

Values are mean \pm SEM. ${ }^{\mathrm{a}} p<0.001,{ }^{\mathrm{b}} p<0.01,{ }^{\mathrm{c}} p<0.05 \mathrm{com}-$ pared with healthy control subjects. FPG, Fasting plasma glucose. LBM, lean body mass

(AER $<20 \mu \mathrm{g} / \mathrm{min}$ ), and c) 19 healthy subjects with normal AER and normal blood pressure. The patients were recruited from the outpatient clinic, and all microalbuminuric Type 2 diabetic patients eligible were included in the study. Microalbuminuria had been present for at least one year. Hypertension was defined as the presence of blood pressure above $160 / 95 \mathrm{~mm} \mathrm{Hg}$ or the use of known treatment for bypertension. Ten microalbuminuric (53\%) and $15(46 \%)$ normoalbuminuric patients had been treated for hypertension for at least 3 years. The proportion of hypertensive patients receiving beta-adrenergic blocking agents $(39 \%$ and $44 \%$ ) and diuretics $(33 \%$ and $22 \%$ ) did not differ between microalbuminuric and normoalbuminuric patients. None of the normotensive patients or control subjects received beta-blocking agents or diuretics. All diabetic patients were treated with sulphonylurea or metformin or both. Treatment with sulphonylurea was stopped 3 days and treatment with metformin 7 days before examination. The clinical characteristics of diabetic and control subjects are shown in Table 1. The Type 2 diabetic patients were further divided into sub-groups based upon whether they had microalbuminuria or hypertension, or both (Table 2). All subjects gave their informed consent before participating in the study. The study protocol was approved by the local ethics committee.

\section{Experimental design}

All subjects participated in the following experiments: 1) a 2-h euglycaemic hyperinsulinaemic clamp with indirect calorimetry and infusion of $\left[{ }^{3} \mathrm{H}-3\right]$-glucose, 2) measurement of lean body mass with the
Table 2. Clinical and metabolic characteristics in normotensive and hypertensive Type 2 diabetic patients with $(\mathrm{MA}+)$ and without $(\mathrm{MA}-)$ microalbuminuria

\begin{tabular}{|c|c|c|c|c|}
\hline \multirow[b]{2}{*}{$n$} & \multicolumn{2}{|c|}{ Hypertensive } & \multicolumn{2}{|c|}{ Normotensive } \\
\hline & $\begin{array}{l}\overline{\mathrm{MA}+} \\
10\end{array}$ & $\begin{array}{l}\mathrm{MA}- \\
15\end{array}$ & $\begin{array}{l}\overline{\mathrm{MA}+} \\
9\end{array}$ & $\begin{array}{l}\mathrm{MA-} \\
18\end{array}$ \\
\hline Age (years) & $59 \pm 3$ & $59 \pm 2$ & $60 \pm 2$ & $59 \pm 2$ \\
\hline Duration (years) & $8 \pm 2$ & $8 \pm 2$ & $9 \pm 3$ & $8 \pm 2$ \\
\hline $\operatorname{BMI}\left(\mathrm{kg} / \mathrm{m}^{2}\right)$ & $28.3 \pm 1.1$ & $27.1 \pm 1.1$ & $27.8 \pm 1.1$ & $25.9 \pm 0.9$ \\
\hline $\operatorname{AER}(\mu \mathrm{g} / \mathrm{min})$ & $83 \pm 17$ & $8 \pm 1$ & $57 \pm 13$ & $6 \pm 1$ \\
\hline $\begin{array}{l}\text { Fasting plasma } \\
\text { glucose (mmol/l) }\end{array}$ & $12.1 \pm 0.8$ & $12.3 \pm 0.6$ & $11.6 \pm 1.4$ & $10.7 \pm 1.4$ \\
\hline $\mathrm{Hb}_{1 \mathrm{c}}(\%)$ & $8.6 \pm 0.3$ & $8.5 \pm 0.3$ & $7.7 \pm 0.5$ & $7.2 \pm 0.4$ \\
\hline $\begin{array}{l}\text { Fasting insulin } \\
(\mathrm{pmol} / \mathrm{l})\end{array}$ & $94 \pm 13^{\mathrm{a}}$ & $99 \pm 16$ & $61 \pm 9$ & $66 \pm 9$ \\
\hline $\begin{array}{l}\text { Systolic } \\
\text { blood pressure } \\
(\mathrm{mmHg})\end{array}$ & $156 \pm 5$ & $150 \pm 5$ & $144 \pm 8$ & $142 \pm 5$ \\
\hline $\begin{array}{l}\text { Diastolic } \\
\text { blood pressure } \\
\text { (mm Hg) }\end{array}$ & $94 \pm 4$ & $90 \pm 3$ & $82 \pm 4$ & $83 \pm 3$ \\
\hline $\begin{array}{l}\text { Basal C-peptide } \\
(\mathrm{nmol} / \mathrm{l})\end{array}$ & $0.61 \pm 0.10$ & $0.54 \pm 0.08$ & $0.37 \pm 0.08$ & $0.39 \pm 0.10$ \\
\hline $\begin{array}{l}\text { Postglucagon } \\
\text { C-peptide } \\
\text { (nmol/l) }\end{array}$ & $1.09 \pm 0.16$ & $0.95 \pm 0.14$ & $0.80 \pm 0.07$ & $0.78 \pm 0.10$ \\
\hline
\end{tabular}

Values are mean \pm SEM. ${ }^{a} p=0.06$ vs normotensive normoalbuminuric patients. AER, Albumin excretion rate

tritiated water technique, and 3) measurement of AER during three different nights.

Glucose metabolism was measured using the euglycaemic insulin clamp technique [13], whereas substrate oxidation was estimated by indirect calorimetry [14]. The clamp was started at 07.30 hours after a 12 h overnight fast. After obtaining three basal samples for glucose and insulin measurements, a primed constant infusion of short-acting human insulin (Actrapid Human; Novo Industri, Copenhagen, Denmark) was administered at a rate of $340 \mathrm{pmol} / \mathrm{m}^{2} \cdot \mathrm{min}$. The plasma glucose concentration was determined at 5-min intervals and a variable infusion of $20 \%$ of glucose was adjusted to maintain the plasma glucose concentration constant. No glucose was infused until plasma glucose had declined to $5.5 \mathrm{mmol} / \mathrm{l}$. The clamps were applied for $120 \mathrm{~min}$ in the control subjects and for $141 \pm 4 \mathrm{~min}$ in the Type 2 diabetic patients. The mean $( \pm S D)$ plasma glucose concentration achieved during the last $60 \mathrm{~min}$ of the clamp in Type 2 diabetic and control subjects were $5.6 \pm 0.7 \mathrm{mmol} / \mathrm{l}$ and $5.2 \pm 0.4 \mathrm{mmol} / 1$, respectively, with a coefficient of variation of $4.2 \%$. The corresponding serum insulin concentrations during the clamp in Type 2 diabetic patients and control subjects were $604 \pm 146 \mathrm{pmol} / \mathrm{l}$ and $559 \pm$ $113 \mathrm{pmol} / 1$, respectively, with a coefficient of variation of $7.4 \%$.

At unchanged plasma glucose concentration, the amount of glucose required to maintain euglycaemia equals whole-body glucose disposal, provided that there is no entry of glucose from the liver. $\mathrm{He}$ patic glucose production was measured by the isotope dilution technique using [ $\left.{ }^{3} \mathrm{H}-3\right]$-glucose (Amersham Inc, Amersham, Bucks, UK) administered as a primed $(25 \mu \mathrm{Ci}$; this dose was increased if the fasting plasma glucose was elevated $)$ - constant $(0.25 \mu \mathrm{Ci} / \mathrm{min})$ infusion for $150 \mathrm{~min}$ before the clamp and continued throughout the experiment. Blood samples for determination of insulin and $\left[{ }^{3} \mathrm{H}-3\right]$-glucose specific activity were obtained in the basal state and at 15 -min intervals throughout the insulin clamp.

Indirect calorimetry was employed in the basal state and during the last $60 \mathrm{~min}$ of the insulin clamp to estimate net rates of glucose and lipid oxidation [14]. A computerized, open-circuit system was 
used to measure gas exchange through a transparent plastic canopy (Deltatrac; Datex, Helsinki, Finland). The monitor has a precision of $2.5 \%$ for oxygen consumption and of $1.0 \%$ for carbon dioxide production. Protein oxidation was calculated from the urinary nitrogen excretion obtained before and during the insulin clamp and corrected for changes in urea clearance.

Lean body mass was determined with the tritiated water technique [15]. AER was measured from urine samples collected during three different nights.

Beta-cell function was assessed by measuring serum C-peptide concentrations before and $6 \mathrm{~min}$ after the i.v. injection of $1 \mathrm{mg}$ of glucagon.

\section{Assays}

The plasma glucose concentration was measured by the glucose oxidase method on a Beckman Glucose Analyzer II (Beckman Instruments, Fullerton, Calif., USA). Glycated haemoglobin concentration in the blood was measured by high pressure liquid chromatography (normal range $=4-6 \%$ ). Plasma insulin was measured by a double-antibody radioimmunoassay (Pharmacia, Uppsala, Sweden). The sensitivity of the insulin assay was $15 \mathrm{pmol} / \mathrm{l}$ and the inter-assay coefficient of variation was $5 \%$. C-peptide concentration was measured by radioimmunoassay, with a sensitivity of $0.02 \mathrm{nmol} / \mathrm{l}$ and inter-assay coefficient of variation of $5.7 \%$. $\left.{ }^{3} \mathrm{H}-3\right]$ glucose specific activity was measured in duplicate on supernatants of 1 mol perchloric acid extract of plasma samples, after evaporation of radiolabelled water. Urinary albumin concentration was measured by a nephelometric method [16]. The sensitivity of the albumin assay was $5 \mathrm{mg} / \mathrm{l}$ and the inter-assay coefficient of variation $6.9 \%$. Serum total cholesterol, HDL cholesterol and triglyceride concentrations were measured by enzymatic assays (Boehringer Mannheim, Mannheim, FRG).

\section{Calculations}

Basal hepatic glucose production was calculated by dividing the infusion rate of $\left[3-{ }^{3} \mathrm{H}\right] \mathrm{glucose}$ by the steady-state plateau of $\left[3-{ }^{3} \mathrm{H}\right] \mathrm{glucose}$ specific activity during the last $30 \mathrm{~min}$ of the baseline tracer-infusion period. After administration of insulin and glucose anon-steady-state condition in glucose specific activity exists, and the rate of glucose appearance was calculated by a non-steady-state equation [17]. This model is known to produce negative estimates of hepatic glucose production at high rates of glucose infusion. Such negative rates of glucose production were observed during the last $60 \mathrm{~min}$ of the clamp in

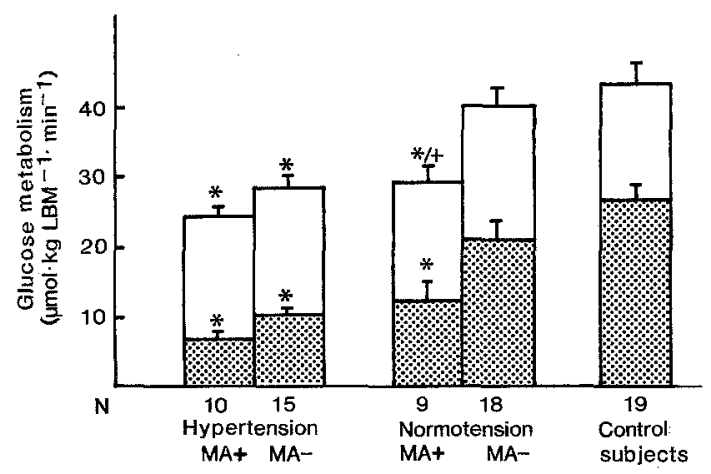

Fig. 1. Rates of insulin-stimulated total glucose metabolism (shown by the height of total bars), glucose oxidation ( $\square$ ) and non-oxidative glucose metabolism (ख) in normotensive and hypertensive Type 2 diabetic patients with (MA + ) and without (MA - ) microalbuminuria. Values are mean $\pm \mathrm{SEM}$. $* p<0.001$ significantly different from control subjects; $+p<0.05$, significantly different from Type 2 diabetic patients wih normal blood pressure and normal albumin excretion rate, LBM, Lean body mass the control subjects but only rarely in the diabetic subjects. The infusion rate of cold glucose was integrated over 20 -min intervals and subtracted from the total rate of glucose appearance to obtain the hepatic glucose production rate. Total body glucose metabolism was calculated by adding the mean rate of hepatic glucose production (if a positive number) during the last $60 \mathrm{~min}$ of the insulin clamp to the mean glucose infusion rate during the same period. Non-oxidative glucose metabolism (mainly storage of glucose as glycogen) [18] was calculated as the difference between total body glucose uptake and glucose oxidation, as determined by indirect calorimetry.

The constants to calculate glucose, lipid and protein oxidation rates from gas exchange data have been published previously [14]. To convert the rate of lipid oxidation to molar units, the values were divided by the molecular weight of a standard triglyceride (861) and multiplied by 3 , i. e. the number of non-esterified fatty acid/triglyceride.

Total body water was calculated from steady-state kinetic data assuming that $1 \mathrm{ml}$ of plasma contains $93 \%$ water [15].

\section{Statistical analysis}

Values are expressed as means \pm SEM. The significance of difference between group means was tested by analysis of covariance using $\mathrm{HbA}_{\mathrm{ic}}$ as covariate. The separate effect of either hypertension or microalbuminuria, or of both, on rates of glucose metabolism was further tested by factorial analysis of variance (ANOVA). The relationship between variables was tested with linear regression analysis.

\section{Results}

The clinical and metabolic characteristics of Type 2 diabetic patients and control subjects are shown in Table 1. Insulin-stimulated glucose metabolism was reduced by $36 \%$ in diabetic patients compared with healthy control subjects $(p<0.001)$. The diabetic patients with hypertension showed a $27 \%$ impairment in their total glucose metabolism $(27.0 \pm 1.3$ vs $36.6 \pm 2.2 \mu \mathrm{mol} \cdot \mathrm{kg}$ $\mathrm{LBM}^{-1} \cdot \mathrm{min}^{-1} ; p<0.001$ ) and a $40 \%$ reduction in the rate of non-oxidative glucose metabolism $(9.9 \pm 1.5$ vs $16.2 \pm 1.7 \mu \mathrm{mol} \cdot \mathrm{kg} \mathrm{LBM}{ }^{-1} \cdot \mathrm{min}^{-1}$ ) compared with normotensive Type 2 diabetic patients (both $p<0.001$ ). Among normotensive Type 2 diabetic patients, the presence of microalbuminuria was associated with a further impairment in glucose metabolism compared with patients with normal albumin excretion rate $(29.4 \pm 2.2 \mathrm{vs}$ $\left.40.5 \pm 2.8 \mu \mathrm{mol} \cdot \mathrm{kg} \mathrm{LBM}{ }^{-1} \cdot \mathrm{min}^{-1}\right) \quad(p=0.012)$ (Fig. 1$)$. The reduction in glucose metabolism in these patients was almost exclusively due to a reduction in the rate of nonoxidative glucose metabolism $12.7 \pm 2.9$ vs $21.1 \pm 2.6$ $\mu \mathrm{mol} \cdot \mathrm{kg} \mathrm{LBM}^{-1} \cdot \mathrm{min}^{-1} ; p=0.06$ vs normoalbuminuric normotensive patients), since the rates of insulin-stimulated glucose oxidation were virtually similar in the two groups $\left(17.0 \pm 0.9 \mathrm{vs} 18.8 \pm 1.2 \mu \mathrm{mol} \cdot \mathrm{kg} \mathrm{LBM}{ }^{-1} \cdot \mathrm{min}^{-1}\right)$. Rates of total and non-oxidative glucose metabolism did not significantly differ between Type 2 diabetic patients without hypertension and microalbuminuria and control subjects. To circumvent the problem with uncertain estimates of hepatic glucose production during the insulin clamp, the actual glucose infusion rates are also given in Table 3. As can be seen, glucose disposal rates are very similar if the actual glucose infusion rates are used as if glucose disposal is expressed as glucose infusion rate plus residual hepatic glucose production (HGP). 
Table 3. Serum lipids, non-esterified fatty acid (NEFA) concentrations and rates of lipid oxidation in hypertensive and normotensive Type 2 diabetic patients with and without microalbuminuria

\begin{tabular}{|c|c|c|c|c|}
\hline \multirow[b]{2}{*}{$n$} & \multicolumn{2}{|l|}{ Hypertensive } & \multicolumn{2}{|l|}{ Normotensive } \\
\hline & $\begin{array}{l}\mathrm{MA}+ \\
10\end{array}$ & $\begin{array}{l}\mathrm{MA}- \\
15\end{array}$ & $\begin{array}{l}\overline{\mathrm{MA}+} \\
9\end{array}$ & $\begin{array}{l}\mathrm{MA}- \\
18\end{array}$ \\
\hline $\begin{array}{l}\text { Total choles- } \\
\text { terol }(\mathrm{mmol} / \mathrm{l})\end{array}$ & $6.4 \pm 0.4$ & $6.6 \pm 0.4$ & $6.9 \pm 0.7$ & $6.4 \pm 0.4$ \\
\hline $\begin{array}{l}\text { HDL choles- } \\
\text { terol }(\mathrm{mmol} / \mathrm{l})\end{array}$ & $1.0 \pm 0.08^{b}$ & $1.2 \pm 0.07$ & $1.21 \pm 0.15$ & $1.37 \pm 0.07$ \\
\hline $\begin{array}{l}\text { Triglycerides } \\
(\mathrm{mmol} / \mathrm{l})\end{array}$ & $3.07 \pm 0.41^{\mathrm{c}}$ & $2.81 \pm 0.56^{\mathrm{c}}$ & c $2.17 \pm 0.25^{\mathrm{a}}$ & $1.49 \pm 0.13$ \\
\hline $\begin{array}{l}\text { Basal serum } \\
\operatorname{NEFA}(\mu \mathrm{mol} / 1)\end{array}$ & $716 \pm 56$ & $846 \pm 52^{b}$ & $736 \pm 67$ & $623 \pm 46$ \\
\hline $\begin{array}{l}\text { Clamp serum } \\
\text { NEFA }(\mu \mathrm{mol} / \mathrm{l})\end{array}$ & $123 \pm 14$ & $123 \pm 52$ & $93 \pm 16$ & $87 \pm 9$ \\
\hline $\begin{array}{l}\text { Basal lipid } \\
\text { oxidation }^{d}\end{array}$ & $5.45 \pm 0.28$ & $5.26 \pm 0.29^{\mathrm{a}}$ & $4.66 \pm 0.57$ & $4.99 \pm 0.3$ \\
\hline $\begin{array}{l}\text { Clamp lipid } \\
\text { oxidation }^{d}\end{array}$ & $3.66 \pm 0.36$ & $3.44 \pm 0.27$ & $2.93 \pm 0.37$ & $2.94 \pm 0.26$ \\
\hline $\begin{array}{l}\text { Glucose } \\
\text { infusion rate }\end{array}$ & 6 & \pm 2.1 & $\pm 2.61^{\circ}$ & $6.13 \pm 3.20$ \\
\hline
\end{tabular}

Values are mean \pm SEM. ${ }^{\mathrm{a}} p<0.05 ;{ }^{\mathrm{b}} p<0.01$; ${ }^{\mathrm{c}} p<0.001$ vs normotensive, normoalbuminuric patients; ${ }^{\mathrm{d}} \mu \mathrm{mol} \cdot \mathrm{kg} \mathrm{LBM}^{-1} \cdot \mathrm{min}^{-1}$

The microalbuminuric hypertensive and microalbuminuric normotensive patients showed higher triglyceride and lower HDL cholesterol concentrations than normotensive normoalbuminuric patients $(p<0.01$ and $p<0.001$ ) (Table 3). There was, however, no significant difference in plasma NEFA concentrations or the rate of lipid oxidation, either in the basal state or during the euglycaemic clamp between the two groups (Table 3). In addition, these patients also showed slightly higher fasting insulin $(p=0.06)$ and C-peptide and postglucagon C-peptide $(p<0.1)$ concentrations than normotensive patients with normal AER.

In a factorial ANOVA design, hypertension but not microalbuminuria was significantly associated with low HDL cholesterol $(p=0.014)$ and high fasting insulin $(p=0.0049)$ concentrations.

\section{Discussion}

Insulin resistance has been considered a characteristic feature of both hypertension and Type 2 diabetes [ $1-5$, 19], and the hypertensive Type 2 diabetic patients of the current study showed a more severe defect in their glucose metabolism than normotensive patients. In contrast to a previous study [5] this reduction was unrelated to the body mass index of the patients. The present study also provides evidence that insulin resistance is related to microalbuminuria in Type 2 diabetic patients. The impairment in glucose metabolism was confined to the non-oxidative pathway, which primarily reflects glycogen formation in skeletal muscle [18]. In addition, the combination of microalbuminuria and hypertension was associated with a clustering of other abnormalities characteristic of the in- sulin resistance syndrome, i. e. hypertriglyceridaemia, low HDL cholesterol and elevated insulin concentrations. These patients also presented with the most severe defect in glucose metabolism, indicating that insulin resistance could be a common denominator for these disturbances.

What could explain the association between insulin resistance and microalbuminuria? Insulin resistance generally leads to hyperinsulinaemia, which is considered necessary to compensate for the reduction in insulin action. The observed abnormalities could therefore, in part, be the consequence of chronic hyperinsulinaemia. Hyperinsulinaemia was observed in both groups of hypertensive patients but not in the normotensive microalbuminuric patients.

Of course, insulin resistance could only be a reflection of the coexisting hypertension and its treatment. Although hypertension was associated with a marked reduction in glucose metabolism, there are some data to suggest that microalbuminuria per se was associated with insulin resistance. First, microalbuminuric patients without hypertension were more insulin resistant than normoalbuminuric patients without hypertension. Second, the rate of insulin-stimulated glucose metabolism correlated inversely with $\operatorname{AER}(R=-0.33 ; p=0.02)$. Third, we have also observed insulin resistance in non-diabetic firstdegree relatives of patients with Type 2 diabetes [20]. In these subjects the rate of glucose disposal showed a strong inverse correlation with AER. It could still be argued that insulin resistance was the consequence of the concomitant treatment with beta-blocking agents and diuretics. This is unlikely, since rates of glucose disposal were similar in hypertensive patients receiving and not receiving the drugs. Although these drugs have been shown to impair insulin sensitivity in normal subjects [21,22], their negative effect on insulin sensitivity may be minor in severely insulin-resistant Type 2 diabetic patients. In keeping with this view, treatment with beta-blocking agents and thiazides was not associated with an increased risk of Type 2 diabetes in insulin-resistant Mexican Americans [23].

Microalbuminuria has been considered as a marker of vascular dysfunction $[10,11,24]$, and associated with an increased transcapillary escape rate of albumin $[25,26]$. Microalbuminuria has also been considered an independent risk factor for cardiovascular disease [9-11,27]. Type 2 diabetic patients with microalbuminuria have elevated levels of von Willebrand factor (vWF) as a sign of endothelial dysfunction [24]. Interestingly, microalbuminuria was associated with an increased risk of cardiovascular disease only in patients with elevated plasma concentrations of vWF [24]. The risk was further modified by the HDL cholesterol concentration. In the present study patients with hypertension and microalbuminuria presented with the lowest HDL cholesterol concentration suggesting that they are at increased risk of cardiovascular disease.

The role of hypertension in this scenario deserves some comments. Essential hypertension per se does not seem to increase the transcapillary escape rate of albumin as in Type 1 diabetic patients with essential hypertension and normal AER, this rate is normal. However, in Type 1 diabetic patients with incipient nephropathy the same elevation in blood pressure and an elevated AER is asso- 
ciated with an increased transcapillary escape rate of albumin. It should be kept in mind that patients classified as normotensive by conventional blood pressure methods, may show elevated blood pressure values during 24-h blood pressure monitoring. Could insulin resistance lead to vascular dysfunction without invoking hypertension? Insulin resistance has also been described in association with microalbuminuria in normotensive Type 1 diabetic patients. These patients were further characterized by increased sodium-lithium countertransport activity $[28,29]$. An inverse relationship was also found between sodiumlithium countertransport activity and insulin-mediated glucose disposal [29]. Increased sodium-lithium countertransport activity could also be the consequence of altered ion exchange across the cell membrane as a result of resistance to the action of insulin. An association between the lipid content of the skeletal muscle cell membrane and the degree of insulin resistance was recently reported in patients with Type 2 diabetes [30]. Alternatively, impaired insulin action could also lead to, or be the consequence of, changes in intracellular calcium and magnesium metabolism [31]. Finally, if sodium proton exchange is increased in insulin resistant individuals in the same way as sodium lithium countertransport, this could lead to sodium retention and impaired transport functions in an expanded sodium pool.

A striking finding was that Type 2 diabetic patients without hypertension and microalbuminuria presented with nearly normal rates of total $(40.9 \pm 2.8$ vs $44.4 \pm$ $\left.2.8 \mu \mathrm{mol} \cdot \mathrm{kg} \mathrm{LBM}{ }^{-1} \cdot \mathrm{min}^{-1} ; p=\mathrm{NS}\right)$ and non-oxidative $\left(21.1 \pm 2.6\right.$ vs $\left.23.6 \pm 2.8 \mu \mathrm{mol} \cdot \mathrm{kg} \mathrm{LBM}{ }^{-1} \cdot \mathrm{min}^{-1} ; p=\mathrm{NS}\right)$ glucose metabolism compared with the healthy control subjects. In addition, their serum lipids were in the same range as observed in the healthy control subjects. The question thus arises, whether these patients represent another form of Type 2 diabetes, in whom insulin deficiency contributes more to the development of hyperglycaemia than insulin resistance. In support of this, the postglucagon C-peptide concentrations tended to be lower in the patients with normal than in the patients with elevated blood pressure $(0.76 \pm 0.07$ vs $1.0 \pm 0.11 \mathrm{nmol} / 1 ; p<0.1)$. A final answer to this question must await appropriate measurements of insulin secretion at matched levels of glycaemia in the patients.

It is, however, obvious that a majority of Type 2 diabetic patients, who display the fullblown picture of the insulin resistance syndrome, i. e. obesity, hypertension and dyslipidaemia demonstrate a marked reduction in skeletal muscle glucose metabolism. Hypertension or microalbuminuria, or both, therefore seem to be markers, which help to subdivide patients with Type 2 diabetes in those with and without insulin resistance. Similar data of near normal glucose metabolism in normotensive Type 2 diabetic patients with normal AER were recently presented in a preliminary report by Solini et al. [32]. Arner et al. [33] also reported normal insulin sensitivity but impaired beta-cell function in non-obese Type 2 diabetic patients.

Taken together, the data indicate that insulin resistance in patients with Type 2 diabetes is primarily confined to those with either hypertension or microalbuminuria or both. The combination of microalbuminuria and hypertension is associated with a clustering of other cardiovascular risk factors such as high triglycerides and low HDL cholesterol concentrations. In contrast, Type 2 diabetic patients with normal blood pressure and normal AER present with nearly normal rates of glucose metabolism. The data thus challenge the view that insulin resistance is an ubiquitous phenomenon in Type 2 diabetes.

Acknowledgements. This study was supported by grants from The Sigrid Juselius Foundation, The Nordisk Insulin Foundation, The Perklén Foundation, Finska Läkaresällskapet and The Wilhelm and Else Stockman Foundation.

\section{References}

1. DeFronzo RA (1988) The triumvirate: $\beta$-cell, muscle, liver. A collusion responsible for NIDDM. Diabetes 37: 667-687

2. Reaven GM (1988) Role of insulin resistance in human disease. Diabetes 37: 1595-1607

3. Groop L, Bonadonna R, Del Prato S et al. (1989) Glucose and free fatty acid metabolism in non-insulin-dependent diabetes mellitus. J Clin Invest 84: 205-213

4. Ferrannini E, Buzzigoli G, Bonadonna R et al. (1987) Insulin resistance in essential hypertension. N Engl J Med 317: 350-357

5. Laakso M, Sarlund H, Mykkänen L (1989) Essential hypertension and insulin resistance in non-insulin-dependent diabetes. Eur J Clin Invest 19: 518-526

6. Viberti GC, Hill RD, Jarrett RJ, Argyropoulus A, Mahmud U, Keen H (1982) Microalbuminuria as a predictor of clinical nephropathy in insulin dependent diabetes mellitus. Lancet I: 1430-1432

7. Mogensen CE, Christensen CK (1984) Predicting diabetic nephropathy in insulin-dependent patients. N Engl J Med 311: 89 93

8. Mogensen CE (1984) Microalbuminuria predicts clinical proteinuria and early mortality in maturity-onset diabetes. N Engl J Med 310: 356-360

9. Jarrett RJ, Viberti GC, Argyropoulus A, Hill RD, Mahmud U, Murrells TJ (1984) Microalbuminuria predicts mortality in noninsulin-dependent diabetes. Diabetic Med 1: 17-19

10. Schmitz A, Vaeth M (1988) Microalbuminuria: a major risk factor in non-insulin-dependent diabetes. A 10-year follow-up study of 503 patients. Diabetic Med 5: 126-134

11. Mattock MB, Keen H, Viberti GC et al. (1988) Coronary heart disease and urinary albumin excretion rate in type 2 (non-insulin-dependent) diabetic patients. Diabetologia 31:82-87

12. Niskanen L, Uusitupa M, Sarlund H et al. (1990) Microalbuminuria predicts the development of serum lipoprotein abnormalities favouring atherogenesis in newly diagnosed type 2 (noninsulin-dependent) diabetic patients. Diabetologia 33: 237-243

13. DeFronzo RA, Tobin JD, Anders R (1979) Glucose clamp technique: a method for quantifying insulin secretion and resistance. Am J Physiol 237: E214-E223

14. Ferrannini E (1988) The theoretical basis of indirect calorimetry: a review. Metabolism 37: 287-301

15. Coleman TG, Manning RD Jr, Norman RA Jr, Guyton AC (1972) Dynamics of water-isotope distribution. Am J Physiol 223: $1371-1375$

16. Teppo AM, Groop L (1985) Urinary excretion of plasma proteins in diabetic subjects. Increased excretion of kappa light chains in diabetic patients with and without proliferative retinopathy. Diabetes 34: 589-594

17. Radziuk J, Norwich KH, Vranic M (1978) Experimental validation of measurements of glucose turnover in non-steady state. Am J Physiol 234: E84-E93

18. Shulman GI, Rothman DL, Jue T, Stein P, DeFronzo RA, Shulman RG (1990) Quantitation of muscle glycogen synthesis in 
normal subjects and subjects with non-insulin-dependent diabetes by ${ }^{13} \mathrm{C}$ nuclear magnetic resonance spectroscopy. $\mathrm{N}$ Engl J Med 322: 223-228

19. Shen D-C, Shieh S-M, Fuh MM-T, Wu D-A, Chen Y-DI, Reaven GM (1988) Resistance to insulin-stimulated-glucose uptake in patients with hypertension. J Clin Endocrinol Metab 66:580-583

20. Forsblom C, Ekstrand A, Eriksson J et al. (1992) Microalbuminuria in non-diabetic first degree relatives of type 2 diabetic patients. Diabetologia 35 [Suppl 1]: A 61 (Abstract)

21. Tötterman K, Groop L, Groop P-H, Kala R, Tolppanen E-M, Fyhrqvist F (1984) Effect of beta-blocking drugs on beta-cell function and insulin sensitivity in hypertensive non-diabetic patients. Eur J Clin Pharmacol 26: 13-17

22. Pollare T, Lithell H, Berne C (1989) A comparison of the effects of hydrochlorothiazide and captopril on glucose and lipid metabolism in patients with hypertension. N Engl J Med 321: 868-873

23. Morales PA, Mitchell BD, Valdez RA, Hazuda HP, Stern MP, Haffner SM (1993) Incidence of NIDDM and impaired glucose tolerance in hypertensive subjects. The San Antonio Heart Study. Diabetes 42: 154-161

24. Stehouwer CDA, Nauta JJP, Zeldenrust GC et al. (1992) Urinary albumin excretion, cardiovascular disease, and endothelial dysfunction in non-insulin dependent diabetes mellitus. Lancet 340: 319-323

25. Jensen T, Bjerre-Knudsen J, Feldt-Rasmussen B, Deckert T (1989) Features of endothelial dysfunction in early diabetic nephropathy. Lancet I: 461-463

26. Nörgaard K, Jensen T, Feldt-Rasmussen B (1993) Transcapillary escape rate of albumin in hypertensive patients with type 1 (insulin-dependent) diabetes mellitus. Diabetologia 36: 57-61

27. Haffner SM, Stern MP, Kozlowski Gruber MK, Hazuda HP, Mitchell BD, Patterson JK (1990) Microalbuminuria. Potential marker for increased cardiovascular risk factors in non-diabetic subjects? Arteriosclerosis 10: 727-731

28. Lopes De Faria JB, Jones SL, MacDonald F, Chambers J, Mattock MB, Viberti GC (1992) Sodium-lithium countertransport activity and insulin resistance in normotensive IDDM patients. Diabetes 41: 610-615

29. Catalano C, Winocour PH, Thomas TH et al. (1993) Erythrocyte sodium-lithium countertransport activity and total body insulinmediated glucose disposal in normoalbuminuric normotensive type 1 (insulin-dependent) diabetic patients. Diabetologia 36: $52-56$

30. Borkman M, Storlien LH, Pan DA, Jenkins AB, Chisholm DJ, Campbell LV (1993) The relation between insulin sensitivity and the fatty-acid composition of skeletal-muscle phospholipids. $\mathrm{N}$ Engl J Med 328: 238-244

31. Resnick LM (1989) Hypertension and abnormal glucose homeostasis. Possible role of divalent ion metabolism. Am J Med 87 [Suppl 6A]: 17 S-22S

32. Solini A, Muollo B, Frigato F et al. (1992) Abnormalities in extrahepatic insulin sensitivity are a peculiar feature of non-insulin dependent diabetic patients with but not without hypertension and/or microalbuminuria. Diabetologia 35 [Suppl 1]: A96 (Abstract)

33. Arner P, Pollare T, Lithell H (1991) Different aetiologies of type 2 (non-insulin dependent) diabetes mellitus in obese and non-obese subjects. Diabetologia 34: 483-487

Received: 16 October 1992

and in revised form: 5 March 1993

Dr. L. Groop

Fourth Department of Medicine

Helsinki University Hospital

Unioninkatu 38

SF-00170 Helsinki

Finland 